\title{
PENTRAXIN-3 LEVEL IN PATIENTS WITH NON-ALCOHOLIC FATTY LIVER DISEASE AND ARTERIAL HYPERTENSION COMORBIDE COURSE DEPENDING ON ENDOTHELIAL DYSFUNCTION PARAMETERS ${ }^{*}$
}

\author{
Ya. Babak, T. M. Holenko \\ Kharkiv National Medical University, Kharkiv, Ukraine \\ holenko.phd.knmu@gmail.com
}

\begin{abstract}
Digestive system diseases are among the hazards to human development in the modern world and pose a threat to the social and economic progress around the world. Liver diseases are numerous among them, in particular, nonalcoholic fatty liver disease (NAFLD), confidently dominating in most countries of todays world according to the parameters of morbidity, incidence, disablement and mortality due to it, especially among young people [1].

Currently NAFLD is considered to be one of the diseases associated with metabolic disorders, including violations of carbohydrate metabolism, coupled with obesity and insulin resistance (IR) [2]. It is now evident that NAFLD, generally perceived as a benign condition, may have on the contrary an important deleterious impact for diabetic patients [3].
\end{abstract}

The presence of NAFLD is believed to be associated with cardiovascular disease (CVD) increased risk. Scientists have suggested a hypothesis that NAFLD is not only CVD marker, but it may also be involved in its pathogenesis [4]. NAFLD and CVD association mechanisms were also investigated, including oxidative stress development, systemic inflammation, IR and hyperlipidemia [5].

Oxidative stress development is the key factor in the emergence of endothelial dysfunction (ED) - the process of cell free radicals cumulation adversely affecting it's function and membrane integrity [6]. ED occupies a prominent place in the pathogenetic mechanisms of CVD and chronic systemic inflammation development [7]. According to a number of researches, a series of vascular inflammation markers be-

* The work was carried out in the framework of the dissertation Holenko T. M. for the degree of Doctor of Philosophy «Improvement of diagnosis and treatment of nonalcoholic fatty liver disease in patients with arterial hypertension, basing on determination the role of petraxin-3» in specialty 14.01 .02 «Internal Diseases», 222 «Medicine» — Kharkiv National Medical University. Written informed consent was obtained from all participants.

Institution, which financed the research: Ministry of Health of Ukraine.

The authors assume responsibility for the published work.

The authors guarantee absence of competing interests and their own financial interest when carrying out the research and writing the article.

The manuscript was received by the editorial staff 2.07.2019. 
ing significant CVD risk factors were reported: levels of fibrinogen [8], C-reactive protein (CRP) [9, 10], uric acid [11], endothelial nitric oxide synthase (eNOS) [12, 13], and the vascular inflammation marker - pentraxin-3.

Currently the scientists attention is attracted by pentraxin- 3 - the recently discovered pentraxin family member. This acute phase protein is released from liver cells, endothelial cells, atherosclerotic lesions, macrophages and neutrophils as a result of systemic inflammation. Compared with CRP, pentraxin-3 is more specific and sensitive marker for CVD development prognosis [14]. An additional point is that CRP primarily reflects general systemic inflammation, while pentraxin-3 is synthesized locally and reflects the vascular system anomaly due to its predominant release from endothelial vascular cells [15]. Thus, numerous studies show that at the pathogenetic level pentraxin-3 is closer associated with ED risk than CRP. However, the criteria proving the role and levels of pentraxin-3 in patients with NAFLD and arterial hypertension (AH) comorbide course are still discussed by the scientists.

Currently the ED problem attracts many researchers, as it is one of the earliest predic- tors of the vascular wall morphological changes, not only at NAFLD, but at AH as well. The ED presence in the peripheral, coronary, micro- and macrocirculation in patients with AH has been proven [16]. Also, endothelium-dependent vasodilation (EDVD) lesion in patients with $\mathrm{AH}$ was determined, that was caused by synthesis disturbance and nitric oxide (NO) release. ED development in hypertensive patients is caused by simultaneous L-arginine-NO system affection and constricting prostaglandins production [17].

However the researches on ED development in the case of NAFLD and AH comorbide course are rare and quite controversial. This fact points out the necessity to investigate the endothelium functional state in patients with NAFLD depending on the presence of $\mathrm{AH}$ taking into account the level of pentraxin-3, the biochemical and echographic endothelial reactivity parameters.

Thus, the object of this research was to find out the possible relation between pentraxin-3, $\mathrm{AH}$ progression stage and endothelial dysfunction in patients with NAFLD and AH comorbide course.

\section{MATERIALS AND METHODS}

46 patients with NAFLD were examined. They were divided into 3 groups: group A included 15 patients with NAFLD (8 men and 7 women, average age of $41 \pm 4.6$ years), group $B$ included 11 patients with NAFLD combined with $\mathrm{AH}$ stage 1 (5 men and 6 women, average age of $42 \pm 3.2$ years) and group C included 20 patients with NAFLD combined with $\mathrm{AH}$ stage 2 (9 men and 11 women, average age of $(42 \pm 4.2$ years). Control group (group D) was formed of 15 apparently healthy people (9 men and 6 women, average age of ( $40 \pm 2.9$ years).

Inclusion criteria were the following: persistently (at least 6 months) elevated aminotransferases, presence of ultrasonographic brightness in liver without any other liver or biliary tract disease. The patients with serologically confirmed liver infectious diseases (including viral hepatitis A, B and chronic hepatitis C), primary biliary cirrhosis, sclerosing cholangitis, chronic inflammatory diseases, chronic cardiac insufficiency, autoimmune rheumatologic diseases (that may also increase pentraxin-3 level in blood), thyroid disorders, oncology diseases, renal insufficiency, pregnant women, as well as aged over 55 years were excluded from the research. The patients were excluded if they were reported to consume more than $20 \mathrm{~g}$ of alcohol daily.

The study was approved by the Ethics Committee of the Kharkiv National Medical University and all participants gave their consent to the study, which was conducted according to the Helsinki Declaration Biological measurements.

NAFLD was diagnosed in accordance with the criteria of the European Association for the Study of the Liver (EASL), the European Association for the Study of Diabetes (EASD) and the European Association for the Study of Obesity (EASO).

$\mathrm{AH}$ was diagnosed under the Order of the Ministry of Health of Ukraine № 384 of May 24, 2012, Unified Clinical Protocol for Medical 
Aid at Arterial Hypertension and the criteria of European (ESH/ESC) Clinical Guidelines for Arterial Hypertension, 2013. The patients with AH stage 1 and 2 were included in the study.

The level of petraxin-3 was determined according to the enzyme multiplied immunoassay method using Human Pentraxin-3 ELISA KIT produced by Multisciences (Lianke) Biotech Co. (China) with Immunochem-2100 immunoenzymometric analyzer (USA).

The endothelium vascular-motor function investigation was performed by the method of brachial artery blood flow dynamics determination at reactive hyperemia. The EDVD (flowdependent dilation) evaluation was carried out by utilizing ULTIMA PA EXPERT ultrasound diagnostic suite (from Radmir Company, Ukraine) with $7.5 \mathrm{MHz}$ linear sensor (resolution $0.01 \mathrm{~mm}$ ) according to the method described by D. Celermajer.

The fibrinogen level was determined according to the Claus method based on the measurement of time required for the formation of insoluble fibrin-polymer in diluted blood plasma after the addition of a large amount of thrombin with the CS5100i automatic coagulometer.

The determination of eNOS concentration in blood plasma was performed following en- zyme multiplied immunoassay method. Serial dilution of eNOS high-concentrated solution (Human Nitric Oxide Synthase 3 (eNOS) ELISA KIT from Biotech Co. (China)) was used to prepare the standard.

The uric acid level was determined by the fermentation method based on the uricase ability to degrade this compound to allantoin, $\mathrm{CO}_{2}$ and $\mathrm{H}_{2} \mathrm{O}_{2}$. The amount of hydrogen peroxide released is determined according to the Trinder reaction - the formation of yellow chromogen in the course of the peroxidase-catalyzed $\mathrm{H}_{2} \mathrm{O}_{2}$ reaction from 4-Aminoantipyrine and 3,5-dichloro-2-hydroxybenzenesulfonate.

CRP level was determined by the photometric turbidimetric method by utilizing Beckman Coulter AU 480 biochemical analyzer (USA).

The results statistical processing was performed with Microsoft Office Excel 2013 and Statistica 13.1 computer programs on a personal computer with the use of parametric (Student's t-test) and non-parametric (MannWhitney U-test) statistical methods. The relationship between variables was analyzed using Spearman's correlations. At the studied groups comparison the error probability was considered to be statistically significant at $\mathrm{p} \leq 0.05$.

\section{RESULTS AND THEIR DISCUSSION}

When comparing the anthropometric measurements of the studied groups (Table 1), average body mass index in the studied patient groups conformed to preobesity, while in the control group preobesity was diagnosed only in $31 \%$ of people. Average systolic and diastolic blood pressure levels in the patient group with NAFLD and AH stage 1 combined course ex-

The studied patient groups anthropometric characteristics

Table 1

\begin{tabular}{c|c|c|c|c|c}
\hline $\begin{array}{c}\text { Patient } \\
\text { groups }\end{array}$ & $\begin{array}{c}\text { Group NAFLD } \\
\text { without AH } \\
(\mathbf{n}=\mathbf{1 5})\end{array}$ & $\begin{array}{c}\text { Group NAFLD } \\
\text { with AH stage 1 } \\
(\mathbf{n}=\mathbf{1 1})\end{array}$ & $\begin{array}{c}\text { Group NAFLD } \\
\text { with AH stage 2 } \\
\mathbf{( n = 2 0 )}\end{array}$ & $\begin{array}{c}\text { Control } \\
\text { Group } \\
\text { (n= 15) }\end{array}$ & $\mathbf{p}^{*}$ \\
\hline Parameters & $53.3 / 46.7$ & $40 / 60$ & $43.8 / 56.2$ & $46.7 / 53.3$ & 0.05 \\
\hline BMI, $\mathrm{kg} / \mathrm{m}^{2}$ & $29.51 \pm 3.31$ & $30.6 \pm 4.21$ & $30.17 \pm 3.86$ & $22.91 \pm 2.7$ & $<0.001$ \\
\hline SBP, Mmhg & $130 \pm 7.0$ & $145 \pm 8.0$ & $160 \pm 11.0$ & $120 \pm 10.0$ & $<0.05$ \\
\hline DBP, Mmhg & $80 \pm 4.0$ & $90 \pm 8.0$ & $100 \pm 9.0$ & $75 \pm 5.0$ & $<0.01$ \\
\hline
\end{tabular}

Note:

The difference from the control group parameters is statistically significant $(\mathrm{p}<0.05)$.

BMI — body mass index;

SBP — systolic blood pressure;

DBP — diastolic blood pressure. 
Indices of endothelial dysfunction

and pentraxin-3 in patients with NAFLD in the presence

or absence of AH stage 1 and 2

\begin{tabular}{|c|c|c|c|c|}
\hline $\begin{array}{r}\text { Patient } \\
\text { groups }\end{array}$ & $\begin{array}{l}\text { Group NAFLD } \\
\text { without AH } \\
(n=15)\end{array}$ & $\begin{array}{l}\text { Group NAFLD } \\
\text { with AH stage } 1 \\
(\mathrm{n}=11)\end{array}$ & $\begin{array}{c}\text { Group NAFLD } \\
\text { with AH stage } 2 \\
(\mathrm{n}=20)\end{array}$ & $\begin{array}{c}\text { Control group } \\
\quad(n=15)\end{array}$ \\
\hline Pentraxin-3, pg/ml & $\begin{array}{c}254.3 \pm 44.4 \\
\mathrm{p}_{1}<0.01\end{array}$ & $\begin{array}{c}421.9 \pm 31.4 \\
\mathrm{p}_{1}<0.01 \\
\mathrm{p}_{2}<0.05\end{array}$ & $\begin{array}{c}430.9 \pm 35.8 \\
\mathrm{p}_{1}<0.01 \\
\mathrm{p}_{3}<0.05 \\
\mathrm{p}_{4}<0.05\end{array}$ & $53.2 \pm 14.3$ \\
\hline $\mathrm{CRP}, \mathrm{mg} / \mathrm{l}$ & $\begin{array}{l}3.8 \pm 3.1 \\
p_{1}<0.01\end{array}$ & $\begin{array}{l}4.1 \pm 2.9 \\
\mathrm{p}_{1}<0.01 \\
\mathrm{p}_{2}<0.05\end{array}$ & $\begin{array}{l}4.3 \pm 2.3 \\
\mathrm{p}_{1}<0.05 \\
\mathrm{p}_{3}<0.05 \\
\mathrm{p}_{4}>0.05\end{array}$ & $0.4 \pm 0.6$ \\
\hline eNOS, pg/ml & $\begin{array}{c}356.7 \pm 18.2 \\
\mathrm{p}_{1}<0.01\end{array}$ & $\begin{array}{c}323.2 \pm 21.3 \\
\mathrm{p}_{1}<0.01 \\
\mathrm{p}_{2}<0.05\end{array}$ & $\begin{array}{c}295.6 \pm 26.7 \\
\mathrm{p}_{1}<0.01 \\
\mathrm{p}_{3}<0.05 \\
\mathrm{p}_{4}<0.05\end{array}$ & $431.5 \pm 34.2$ \\
\hline Fibrinogen, g/l & $\begin{array}{c}3.8 \pm 0.21 \\
\mathrm{p}_{1}<0.05\end{array}$ & $\begin{array}{l}4.2 \pm 0.20 \\
\mathrm{p}_{1}<0.05 \\
\mathrm{p}_{2}<0.05\end{array}$ & $\begin{array}{l}4.4 \pm 0.19 \\
\mathrm{p}_{1}<0.05 \\
\mathrm{p}_{3}<0.05 \\
\mathrm{p}_{4}>0.05\end{array}$ & $2.4 \pm 0.21$ \\
\hline Uric acid, umol/l & $\begin{array}{c}411 \pm 2.21 \\
\mathrm{p}_{1}<0.01\end{array}$ & $\begin{array}{c}428 \pm 2.05 \\
\mathrm{p}_{1}<0.01 \\
\mathrm{p}_{2}<0.05\end{array}$ & $\begin{array}{c}436 \pm 4.11 \\
\mathrm{p}_{1}<0.01 \\
\mathrm{p}_{3}<0.05 \\
\mathrm{p}_{4}<0.05\end{array}$ & $308 \pm 6.0$ \\
\hline EDVD, \% & $\begin{array}{c}2.15 \pm 1.0 \\
\mathrm{p}_{1}<0.01\end{array}$ & $\begin{array}{l}2.08 \pm 2.4 \\
\mathrm{p}_{1}<0.01 \\
\mathrm{p}_{2}<0.05\end{array}$ & $\begin{array}{l}1.86 \pm 3.3 \\
\mathrm{p}_{1}<0.01 \\
\mathrm{p}_{3}<0.05 \\
\mathrm{p}_{4}<0.05\end{array}$ & $3.07 \pm 0.8$ \\
\hline
\end{tabular}

Note:

$\mathrm{p}_{1}$ the probability of changes compared to the control group;

$\mathrm{p}_{2}$ the probability of changes in the group NAFLD without AH compared to the group NAFLD with AH stage 1;

$\mathrm{p}_{3}$ the probability of changes in the group NAFLD without AH compared to the group NAFLD with AH stage 2;

$\mathrm{p}_{4}$ the probability of changes in the group NAFLD with AH stage 1 compared to the group NAFLD with AH stage 2.

CRP - C-reactive protein,

eNOS - endothelial nitric oxide,

EDVD - endothelium-dependent vasodilation.

ceeded the levels of the group with NAFLD and AH stage 2 and conformed to the AH stage 1 and 2 respectively according to the WHO classification (1999) $(\mathrm{p}<0.05)$.

The obtained data on endothelial dysfunction parameters and pentraxin-3 level (Table 2) evidence pentraxin-3 level significant increase in blood plasma of patients with NAFLD with underlying $\mathrm{AH}$ compared to the patient group with NAFLD with no underlying AH $(\mathrm{p}<0.05)$ and to the control group $(p<0.01)$. Also sta- tistical difference of pentraxin-3 level in the group of patients with NAFLD and AH stage 1 compared to the group with NAFLD and AH stage 2 was found $(p<0.05)$.

CRP level analysis evidenced it's increase in the group of patients with NAFLD and AH stage 2 and 2 compared to the group of patients with NAFLD without AH $(p<0.05)$ and the control group $(p<0.01)$. However no significant difference of this parameter between the groups of patients with NAFLD and AH 
stage 2 and patients with NAFLD and AH stage 1 was found ( $p>0.05$ ).

eNOS level analysis evidenced gradual decrease of this vasodilator in blood of patients with NAFLD both with and without AH compared to the control group $(p<0.01)$. However, the most pronounced decrease of eNOS was in the group NAFLD and AH stage 2 comorbide course compared to the group NAFLD without $\mathrm{AH}(\mathrm{p}<0.05)$ and the control group $(\mathrm{p}<0.01)$. Also statistical difference of eNOS level in the group of patients with NAFLD and AH stage 1 compared to the group with NAFLD and AH stage 2 was found $(p<0.05)$.

While comparing the fibrinogen level in the studied patient groups it is important to emphasize the gradual slight increase of this parameter in the groups of patients with NAFLD both with and without AH compared to the control group $(p>0.05)$. However no significant difference of fibrinogen level between the groups of patients with NAFLD and AH stage 2 and patients with NAFLD and AH stage 1 was found $(\mathrm{p}>0.05)$.

Uric acid level was statistically increased in group NAFLD with AH stage 2 compared to the group NAFLD without AH $(p<0.05)$ and control group $(p<0.01)$. It was also determined that uric acid level was higher when comparing the groups of patients with NAFLD and AH stage 1 and AH stage $2(p<0.05)$.

Statistical EDVD decrease was evidenced in patients with NAFLD and AH both stages compared to the group NAFLD with no $\mathrm{AH}$ $(p<0.05)$ and control group $(p<0.01)$.

The analysis of correlation between pentraxin- 3 and the studied parameters revealed a negative correlation between pentraxin- 3 and eNOS $(R=-0.76 ; p<0.05)$, pentraxin-3 and $\operatorname{EDVD}(\mathrm{R}=-0,73 ; \mathrm{p}<0,05)$. A positive correlation was found between pentraxin-3 and the levels of CRP $(\mathrm{R}=+0.78 ; \mathrm{p}<0.05)$, fibrinogen $(\mathrm{R}=+0.39 ; \mathrm{p}<0.05)$, and uric acid $(\mathrm{R}=+0.41$; $\mathrm{p}<0.05)$. Analyzing the correlation obtained we may assume the presence of statistical pathogenetic relationship between pentraxin-3, eNOS, EDVD, CRP and endothelial dysfunction development in patients with NAFLD and AH comorbide course.

Pentraxin-3 is a novel biological marker of inflammatory processes. Many diseases which have some inflammatory characteristics and have potential to cause endothelial dysfunction can lead to increased serum pentraxin-3 levels [18]. In a study, it was shown that pentraxin-3 induced dysfunction and morphological changes in the endothelial layer through a P-selectin/ matrix metalloproteinase-1 pathway [20]. Higashi et al. demonstrated that endotheliumdependent vasodilation was blunted through a decline in the no release in patients with NAFLD [21]. Previous studies demonstrate that pentraxin-3 is involved in a variety of molecular mechanisms which can eventually lead to ED, inflammation, and increased arterial stiffness in hypertensive patients [19].These data are also consistent with our study findings. According to our results, there is a close association between elevated pentraxin-3 levels and ED in hypertensive patients with NAFLD. Furthermore, our data are also consistent with the literature findings which have shown the potential importance of serum pentraxin-3 levels as compared to some other markers in the determination of clinical diagnosis and prognosis of ED and inflammation.

This study has some limitations. Firstly, because of the small sample size and the strict inclusion criteria, the findings obtained are not representative for all subjects with NAFLD. Secondly, further prospective studies should be arranged to clarify the cause-and-effect relationship and test whether quantification of pentraxin-3 levels could provide additional information beyond the currently recognized risk factors to predict future cardiovascular events in subjects with NAFLD and AH comorbide course.

\section{CONCLUSIONS}

1. The research performed has showed that the patients with NAFLD and AH comorbide course have statistically higher pentraxin-3 level compared to the patients with isolated NAFLD course.
2. Correlation between pentraxin-3, eNOS, CRP and EDVD levels has been found in patients with NAFLD and AH comorbide course, that may evidence the pathogenetic role of pentraxin-3 in the endothelial dysfunction de- 
velopment and progression in this cohort of patient.

3. It has been found that pentraxin-3 levels and endothelial reactivity parameters were statistically increased through $\mathrm{AH}$ progression in patients with NAFLD with underlying $\mathrm{AH}$ that may indicate an independent influence of $\mathrm{AH}$ on the endothelial dysfunction development.

\section{REFERENCES}

1. Younossi Z, Anstee QM, Bugianesi E, et al. Nat Rev Gastroenterol Hepatol 2018; 15(1): 11-20. doi: 10.1038/ nrgastro.2017.109.

2. Samuel VT, Shulman GI. Cell Metab 2018; 27(1): 22-41. doi: 10.1016/j.cmet.2017.08.002.

3. Radaelli MG, Martucci F, et al. J Endocrinol Invest 2018; 41(5): 509-521. doi: 10.1007/s40618-017-0799-3.

4. Motamed N, Rabiee B, et al. Clin Res Hepatol Gastroenterol 2017; 41(1): 31-38. doi: 10.1016/j.clinre.2016.07.005.

5. Leach NV, Dronca E, et al. Eur J Intern Med 2014; 25(8): 762-767. doi: 10.1016/j.ejim.2014.09.007.

6. Privistirescu AI, Sima A, et al. Can J Physiol Pharmacol 2018; 96(10): 1012-1016. doi: 10.1139/cjpp-20180119.

7. Corban MT, et al. Arterioscler Thromb Vasc Biol 2019; 39(7): 1272-1274. doi: 10.1161/ATVBAHA.119.312836.

8. Bridge KI, et al. Thromb Haemost 2014; 112(5): 901908. doi: 10.1160/TH14-02-0184.

9. Badimon L, Peña E, et al. Front Immunol 2018; 9: 430. doi: 10.3389/fimmu.2018.00430.

10. Liu HH, Cao YX, et al. Hypertens Res 2019. doi: 10.1038/ s41440-019-0293-8.

11. Kleber ME, Delgado G, et al. J Am Soc Nephrol 2015; 26(11): 2831-2838. doi: 10.1681/ASN.2014070660.
12. Li P, Zhang L, et al. Int J Mol Med 2016; 37(4): 989-997. doi: 10.3892/ijmm.2016.2491.

13. da Silva RF, Trapé ÁA, et al. PLoS One 2018; 13(10): e0206254. doi: 10.1371/journal.pone.0206254.

14. Ristagno G, Fumagalli F, et al. Front Immunol 2019; 10: 823. doi: 10.3389/fimmu.2019.00823.

15. Vyas VS, Longhi MP. Cardiovasc Res 2019: cvz146. doi: $10.1093 /$ cvr/cvz146.

16. Popovici B, Brumaru O. Rev Med Chir Soc Med Nat Iasi 2011; 115(1): 85-90.

17. Maruhashi T, et al. J Hypertens 2018; 36(7): 1460-1467. doi: 10.1097/HJH.0000000000001750.

18. Lopez-Lopez J, Lopez-Jaramillo P, Camacho PA, et al. Mediators Inflamm 2015; 2015:710613. doi: 10.1155/ 2015/710613.

19. Igari K, Kudo T, Toyofuku T, Inoue Y. Int J Vasc Med 2016; 2016: 1-6. doi: 10.1155/2016/6015701.

20. Carrizzo A, Lenzi P, Procaccini C, et al. Circulation 2015; 131: 1495-1505. doi: 10.1161/CIRCULATIONAHA. 114.014822 .

21. Higashi Y, Nakagawa K, Kimura M, et al. J Am Coll Cardiol 2002; 40(11): 2039-2043. doi: 10.1016/s07351097(02)02535-4. 


\title{
PENTAXIN-3 LEVEL IN PATIENTS \\ WITH NONALCOHOLIC FATTY LIVER DISEASE \\ AND ARTERIAL HYPERTENSION COMORBIDE COURSE DEPENDING ON ENDOTHELIAL DYSFUNCTION PARAMETERS
}

\author{
O. Ya. Babak, T. M. Holenko
}

Kharkiv National Medical University, Kharkiv, Ukraine

holenko.phd.knmu@gmail.com

The object of this research was to find out the possible relation between pentraxin-3, AH progression stage and ED in patients with NAFLD and AH comorbide course.

Materials and methods. 46 patients with NAFLD were examined. They were sorted into 3 groups: group A (15 patients with NAFLD), group B (11 patients with NAFLD combined with AH stage 1) and group C (20 patients with NAFLD combined with AH stage 2). Control group (group D) was formed of 15 apparently healthy people. Pentraxin-3, endothelial nitric oxide (eNOS), endothelium-dependent vasodilation (EDVD), C-reactive protein (CRP), fibrinogen and uric acid levels were determined in this study.

Results and discussion. It has been established that the level of pentraxin-3 in blood plasma is significantly increased in the groups B and C compared with group A $(p<0,05)$ and group D $(p<0.01)$. Also, a significant increase of pentraxin-3 level in the group $\mathrm{C}$ compared with the group B was found $(\mathrm{p}<0.05)$. The negative correlation was found between pentraxin-3 and eNOS $(R=-0.76 ; p<0.05)$ and EDVD $(R=-0,73$; $\mathrm{p}<0,05)$. The positive correlation was found between pentraxin-3 and levels of $\mathrm{CRP}(\mathrm{R}=+0.78 ; \mathrm{p}<0.05)$, fibrinogen $(\mathrm{R}=+0,39 ; \mathrm{p}<0,05)$ and uric acid $(\mathrm{R}=+0,41 ; \mathrm{p}<0,05)$.

Conclusions. The research performed has showed that the patients with NAFLD and AH comorbide course have statistically higher pentraxin-3 levels compared to the patients with isolated NAFLD course. Correlation between pentraxin-3, eNOS, CRP and EDVD in hypertensive patients with NAFLD may indicate the pathogenetic role of pentraxin-3 in the ED development and progression in this cohort of patient. It has been found that pentraxin-3 levels and endothelial reactivity parameters were statistically increased through $\mathrm{AH}$ progression in patients with NAFLD with underlying $\mathrm{AH}$, that may indicate an independent effect of $\mathrm{AH}$ on the endothelial dysfunction development.

Key words: nonalcoholic fatty liver disease, arterial hypertension, oxidative stress, endothelial dysfunction, pentraxin-3.

\section{РІВЕНЬ ПЕНТРАКСИНУ-З У ПАЦІЄНТІВ З КОМОРБІДНІМ ПЕРЕБІГОМ НЕАЛКОГОЛЬНОЇ ЖИРОВОЇ ХВОРОБИ ПЕЧІНКИ ТА ГІПЕРТОНІЧНОЇ ХВОРОБИ В ЗАЛЕЖНОСТІ ВІД ПОКАЗНИКІВ ЕНДОТЕЛІАЛЬНОЇ ДИСФУНКЦІЇ}

Бабак О. Я., Голенко Т. М.

Харківський національний медичний університет, м. Харків, Украӥна holenko.phd.knmu@gmail.com

Мета роботи полягала у виявленні можливого зв'язку пентраксину-3 зі ступенем прогресування ГХ та порушенням функції ендотелію у пацієнтів з коморбідним перебігом НАЖХП та ГХ.

Матеріали та методи. Обстежено 46 пацієнтів з НАЖХП. Досліджувані пацієнти були розділені на 3 групи: група А (15 паціентів з НАЖХП), група В (11 пацієнтів з НАЖХП в поєднанні з ГХ 1 ст.) та група C (20 паціентів з НАЖХП в поєднанні з ГХ 2 ст.). Контрольна група (група D) включала 15 практично здорових осіб. У дослідженні вивчалися рівні пентраксину-3, ендотеліальної синтази оксиду азоту (eNOS), ендотелій-залежної вазодилятації (ЕЗВД), С-реактивного білка (СРБ), фрібриногену і сечової кислоти.

Результати та обговорення. Було встановлено, що рівень пентраксину-3 в плазмі крові значно підвищений в групах В і C в порівнянні з групою A $(\mathrm{p}<0,05)$ і групою D (p < 0,01). Також було виявлено підвищення рівня пентраксину-3 в групі С в порівнянні з групою В ( $<0,05)$. Негативна кореляція була знайдена між пентраксином-3 та рівнем $\operatorname{eNOS}(\mathrm{R}=-0,76 ; \mathrm{p}<0,05)$, ЕЗВД $(\mathrm{R}=-0,73 ; \mathrm{p}<0,05)$. Позитивна кореляція була виявлена між пентраксином- 3 та рівнями СРБ $(\mathrm{R}=+0,78 ; \mathrm{p}<0,05)$, фрібриногену $(\mathrm{R}=+0,39 ; \mathrm{p}<0,05)$ та сечової кислоти $(\mathrm{R}=+0,41 ; \mathrm{p}<0,05)$.

Висновки. Паціенти з коморбідним перебігом НАЖХП та ГХ мають достовірно вищі рівні пентраксину-3 в порівнянні з паціентами з НАЖХП без ГХ. У паціентів з коморбідним перебігом НАЖХП та ГХ був виявлений взаємозв'язок між рівнем пентраксину-3, eNOS, CPБ і ЕЗВД, що може свідчити про патогенетичну роль пентраксину-3 в розвитку і прогресуванні ЕД у даної когорти пацієнтів. Також, у пацієнтів з коморбідним перебігом НАЖХП та ГХ було встановлено достовірне підвищення рівнів пентраксину-3 і показників ЕД в міру прогресування ГХ, що може вказувати на самостійний внесок ГХ в розвиток ЕД.

К л ючові слов а: неалкогольна жирова хвороба печінки, гіпертонічна хвороба, окислювальний стрес, ендотеліальна дисфункція, пентраксин-3. 


\section{УРОВЕНЬ ПЕНТРАКСИНА-З У ПАЦИЕНТОВ \\ С КОМОРБИДНЫМ ТЕЧЕНИЕМ НЕАЛКОГОЛЬНОЙ ЖИРОВОЙ БОЛЕЗНИ ПЕЧЕНИ И ГИПЕРТОНИЧЕСКОЙ БОЛЕЗНИ В ЗАВИСИМОСТИ ОТ ПОКАЗАТЕЛЕЙ ЭНДОТЕЛИАЛЬНОЙ ДИСФУНКЦИИ}

Бабак О. Я., Голенко Т. Н.

Харьковский национальный медицинский университет, г. Харьков, Украина holenko.phd.knmu@gmail.com

Цель работы заключалась в выявлении возможной связи пентраксина-3 со степенью прогрессирования ГБ и нарушением функции эндотелия у пациентов с коморбидным течением НАЖБП и ГБ.

Материалы и методы. Обследовано 46 пациентов с НАЖБП. Исследуемые были разделены на 3 группы: группа А (15 пациентов с НАЖБП), группа В (11 пациентов с НАЖБП в сочетании с ГБ 1 ст.) и группа С (20 пациентов с НАЖБП в сочетании с ГБ 2 ст.). Контрольная группа (группа D) включала 15 практически здоровых индивидов. В исследовании изучались уровни пентраксина-3, эндотелиальной синтазы оксида азота (eNOS), эндотелий-зависимой вазодилятации (ЭЗВД), C-реактивного белка (СРБ), фрибриногена и мочевой кислоты.

Результаты и обсуждение. Было установлено, что уровень пентраксина-3 в плазме крови значительно повышен в группах В и С в сравнении с группами A $(p<0,05)$ и $\mathrm{D}(\mathrm{p}<0,01)$. Также было обнаружено значительное повышение уровня пентраксина-3 в группе $\mathrm{C}$ в сравнении с группой $\mathrm{B}(\mathrm{p}<0,05)$. Отрицательная корреляция была найдена между пентраксином-3 и уровнем eNOS $(\mathrm{R}=-0,76 ; \mathrm{p}<0,05)$, ЭЗВД $(\mathrm{R}=-0,73 ; \mathrm{p}<0,05)$. Положительная корреляция была обнаружена между пентраксином-3 и уровнями СРБ $(\mathrm{R}=+0,78 ; \mathrm{p}<0,05)$, фоибриногена $(\mathrm{R}=+0,39 ; \mathrm{p}<0,05)$ и мочевой кислоты $(\mathrm{R}=+0,41$; $\mathrm{p}<0,05)$.

Выводы. Пациенты с коморбидным течением НАЖБП и ГБ имеют достоверно более высокие уровни пентраксина-3 в сравнении с пациентами с НАЖБП без ГБ. У пациентов с коморбидным течением НАЖБП и ГБ была выявлена взаимосвязь между уровнем пентраксина-3, eNOS, CРБ и ЭЗВД, что может свидетельствовать о патогенетической роли пентраксина-3 в развитии и прогрессировании ЭД у данной когорты пациентов. Также, у пациентов с коморбидным течением НАЖБП и ГБ было установлено достоверное повышение уровней пентраксина-3 и показателей ЭД по мере прогрессирования ГБ, что может указывать на самостоятельный вклад ГБ в развитие ЭД.

Ключевые слова: неалкогольная жировая болезнь печени, гипертоническая болезнь, окислительный стресс, эндотелиальная дисфункция, пентраксин-3. 